Teologia i Moralność, Volumen 15(2020), numer 2(28)

doi: 10.14746/tim.2020.28.2.01

ORCID: 0000-0002-6788-9452

LADISLAV CSONTOS

Trnava University

Faculty of Theology, Bratislava

\title{
Grandparents and the transmission of the faith and Christian lifestyle ${ }^{1}$
}

\section{Preface}

In the past centuries Christian faith was transmitted from generation to generation within the family and this process was considered as a matter of course. Children grew up by the side of their parents and grandparents and the reality of family was understood and lived in a much broader way than today when family is usually conceived as "nuclear family" consisting of parents and their children only; grandparents seldom represent a part of it. The families prayed together, managed their domestic economy together, gathered together around the table, spent the moments of rest together, and celebrated feasts together. Their life was integrated into the local community whose members knew and helped each other in difficult situations. In the past the multigenerational housing was a necessity; the acquirement of their own house was a long-term objective of virtually every young family who strived to gain their independence. To put it short and simply, it was a matter of considerable financial investment, which also applies to the current situation. In Slovakia, young families get huge mortgages to buy their own house or apartment; the demand for long-term, affordable rental housing far exceeds supply.

In spite of this trend there is also the tendency towards multigenerational housing. Of course, this tendency does not represent a return to the previous style of housing where all the members of the household lived in a single room and kitchen. It leads to living in multigenerational house or apartment inhab-

${ }^{1}$ The study is a part of the project APVV 15-0189: "Selected Factors of the Pro-Family Strategy and the Support of Stable Family in a Multicultural Environment". 
ited by two separated households that have the possibility to share their lives and provide each other with mutual help. In order to achieve this, it is necessary for each household to have their own privacy. Even in case they share some spaces, some of them must be separated, namely bedroom, kitchen, and bathroom. This model of housing makes it possible for grandparents to be of help taking care of grandchildren and transmitting faith to them in a natural, spontaneous way. On the other hand, the young couples can help the ageing grandparents. The advocates of this model of housing also point to the fact that it leads to reduced cost of living.

We are not concerned with economic reasons but the transmission of faith from generation to generation. It was precisely grandparents who used to play an important role in this process. This fact has been known since antiquity two thousand years ago St. Paul wrote in the Second Epistle to Timothy: "I am reminded of your sincere faith, a faith that dwelt first in your grandmother Lo'is and your mother Eunice and now, I am sure, dwells in you" (2 Tim 1:5). There was unbroken continuity linking together Timothy's faith with the faith of his mother and grandmother. Reading these words, we can see a parallel with the present situation - today's grandparents often care about the Christian formation of their grandchildren more than parents themselves who are not infrequently infected by religious indifference. In the following text we will deal with grandparents' role of transmitters of the faith and, based on sociological surveys on the religiosity of Catholics in Slovakia, we will try to identify the problems and signs of hope related to the transmission of the faith from generation to generation.

\section{Grandparents and the transmission of the faith in general}

European surveys reveal the disappearance of the faith and point to the need of giving more conscious testimony to one's faith in the context of our usual environment. One of the indicators pointing to this fact is high divorce rate. Trying to identify the factors increasing the stability of the current family we should highlight a very valuable contribution of the grandparents to their own families consisting in transmission of the faith to their grandchildren (Braunsteiner 2017, 13).

In connection with this it is important to keep in mind the basic characteristics of Christian community as described in the Acts of the Apostles: "And they devoted themselves to the apostles' teaching and fellowship, to the breaking of bread and the prayers" (Acts 2:42). The basic dimensions of early Christians' life were: teaching, fellowship, prayer, Eucharist and hospitality. In Jerusalem and Corinth, the basic Christian communities were formed in families. 
Today it is emphasised that every parish needs more family spirit and each family needs more ecclesial spirit. The gatherings taking place in the homes of families remain the privileged place of proclamation, growth and missionary activity of the Christian community. Reading the opening chapters of St. Paul's letters we learn that the God's Church is formed from the individual domestic churches. In addition to recalling the gatherings of Israel the apostle to the Gentiles points to the fact that the Church is based on the principle of koinonia, which means that it consists of communities gathering in family houses (i.e. around the hosting families) found in the towns and regions inhabited by local Churches. The organisational structure of the early Church was situated within the space defined by two mutually interconnected coordinates: family dimension of the Church and ecclesial dimension of the family. The family dimension of the early Church consisted in the fact that dwelling places together with families living there represented not only a spatial point but above all basic units, living cells forming the organism of the universal Church, basic units and cells giving rise to the living reality of professing faith and proclaiming Gospel in Jewish and pagan world. Within this organisational structure domestic churches represent a living tissue of ecclesial organism. Like in case of every living organism, in these cells, too, the processes of assimilation and multiplication take place: "The Church and family are linked by a relationship characterised by mutual reciprocity: The Church is the mother who gives birth to every newly baptised infusing him/her with the life of Christ; the family raises her children and accompanies them on their way of growth being aware that she was made participant in the "nuptial mystery" of the Church, the Bride of the Word (Eph 5:21-33) and committed herself to follow family precepts she received (Eph 6:1-4; Col 3:18-23; 1 Pet 3:1-7). The family is presented as locus theologicus within and through which the faith is transmitted, the Passover of the Resurrected celebrated and the proclamation of salvation carried out (Rocchetta 2011, 394-395).

The Apostolic exhortation Catechesi tradendae of Pope John Paul II reminds us of the following: "One moment that is often decisive is the one at which the very young child receives the first elements of catechesis from its parents and the family surroundings. These elements will perhaps be no more than a simple revelation of a good and provident Father in heaven to whom the child learns to turn its heart. The very short prayers that the child learns to lisp will be the start of a loving dialogue with this hidden God whose word it will then begin to hear. I cannot insist too strongly on this early initiation by Christian parents in which the child's faculties are integrated into a living relationship with God. It is a work of prime importance. It demands great love and profound respect for the child who has a right to simple and true presentation of the Christian faith" (John Paul II 1979, 36). 
Gloria Braunsteiner writes that in the contemporary society the following phenomenon can be observed: under the pressure of everyday tasks parents loose the sense of religious education and subsequently do not perceive any need to transmit the faith to their children. The reason is that the parents themselves received the faith but do not follow its practical implications. In the families of this kind the grandparents gain particular importance with regard to this area. Those of them who reached true personal maturity can point to the roots and origin of man. According to the surveys carried out in German speaking countries the most active and committed persons entering the process of transmitting religiosity to the youngest generation are grandmothers. These findings are far from having a mere local validity - they correspond to the data obtained in other countries. Many children of unmarried couples live with grandparents who raise them. Besides this, religion has recently become utterly private matter and the upbringing of children is increasingly influenced by electronic media. The influence of family on the upbringing of children is permanently decreasing; in non-religious context the impact of grandparents is virtually non-existing or minimal. In many cases scholastic religious education cannot build on the religious experience that the child has had in the family which is a serious problem as the school is never able to replace the family. In this situation grandparents can play an important role as they are often able to offer a tangible Christian testimony to their grandchildren who can see the authenticity of their being. It is in particular grandmothers who are able to provide the grandchildren with the answers adequate to the degree of their cognitive abilities. Today a multigenerational household is a rare phenomenon although this way of living could often be beneficial for all persons involved. For many families the ideal relationship with the (grand)parents is represented by intimacy combined with detachment. However, from the viewpoint of grandchildren this model is rather a disadvantage as the lacking spontaneous contact with the grandparents leads to mutual estrangement. In the contemporary society there are various types of grandparents, for example foster parents, wise advisers, joy seekers, or the detached ones. It is worth noting that today the religious education is usually received via female line - through one's mother, grandmother, aunt, sister or friend. Most times it is grandmothers who keep alive and transmit important family and cultural traditions that are often connected with the life of the Church. They remember the life lived without most of today's technical achievements and are able to compare it with the present time; this ability is even stronger if they remember the war years during which people experienced total social and material insecurity (Braunsteiner 2017, 13-14).

These traditions include in the first place personal prayer, the dialogues about the faith, the participation in the life of parish community, most impor- 
tantly in the Sunday Holy Mass, and the contact with priest. Among others these issues were recently examined by two sociological surveys on the religiosity of Slovak Catholics. In the following text we will analyse their outcomes.

\section{Transmission of the faith to the children in families}

The above mentioned sociological surveys on the religiosity of Slovak Catholics follow the line established by the enquiries conducted by Władysław Piwowarski who analysed the issues of transmission of the faith in the context of religious socialisation. Beside this they make use of foreign surveys carried out in various countries. Piwowarski pointed to the fact that in a pluralist society the religious function of the family is far from being a universal phenomenon. The individual families fulfil it to a greater or lesser degree. This is the crucial issue since the religiosity of children depends above all on the religiosity of their parents. The survey on the religiosity of Slovak Catholics in the productive age carried out in 2007 including among others the examination of the transmission of the faith to children in families revealed several negative but also positive trends. We will begin with the question if and how often the families of respondents prayed together when they were children and teenagers. Immediately after this, the questionnaire lists another question: Who taught you how to pray when you were a child? When they were children, $50 \%$ of respondents took part in joint family prayer at least once a week.

Tab. 1: The answers to the question: When you were, say, 10 years old, did you pray together as a family? If you did so, how often was it?

\begin{tabular}{|l|c|c|c|}
\hline Answer & Abs. & \% & Cumulative \% \\
\hline Every day & 234 & 18.2 & 18.2 \\
\hline Several times a week & 221 & 17.2 & 35.4 \\
\hline Once a week & 188 & 14.6 & 50.0 \\
\hline About once a month & 64 & 5.0 & 55.0 \\
\hline Less frequently & 290 & 22.6 & 77.5 \\
\hline Never & 289 & 22.5 & 100.0 \\
\hline Sum total & $\mathbf{1 2 8 6}$ & $\mathbf{1 0 0 . 0}$ & \\
\hline
\end{tabular}

With the increasing age of child, particularly in the period of adolescence, the rate of this practice decreases to less than $30 \%$. 
Tab. 2: The answers to the question: When you were, say, 16 years old, did you pray together as a family? If you did so, how often was it?

\begin{tabular}{|l|c|c|c|}
\hline Answer & Abs. & \% & Cumulative \% \\
\hline Every day & 96 & 7.6 & 7.6 \\
\hline Several times a week & 115 & 9.1 & 16.6 \\
\hline Once a week & 159 & 12.5 & 29.2 \\
\hline About once a month & 88 & 6.9 & 36.1 \\
\hline Less frequently & 352 & 27.8 & 63.9 \\
\hline Never & 458 & 36.1 & 100.0 \\
\hline Sum total & $\mathbf{1 2 6 8}$ & $\mathbf{1 0 0 . 0}$ & \\
\hline
\end{tabular}

Statistically significant differences were detected among individual age groups when answering the question about the practise of the joint prayer in their families during their childhood and adolescence. In both cases it was older respondents who prayed more often, which indicates that the practice of joint prayer is disappearing from our families.

Tab. 3: The answers to the question: When you were, say, 16 years old, did you pray together as a family? If you did so, how often was it? (the variable of age taken into account) $n=1268$

\begin{tabular}{|l|r|r|r|r|r|}
\hline Answer & $\begin{array}{c}\text { Less than } \\
\text { 30 years }\end{array}$ & $\mathbf{3 0 - 3 9}$ years & $\mathbf{4 0 - 4 9}$ years & $\begin{array}{c}\text { 50 years } \\
\text { and more }\end{array}$ & Sum total \\
\hline Every day & $5.9 \%$ & $6.6 \%$ & $6.0 \%$ & $13.4 \%$ & $7.6 \%$ \\
\hline Several times a week & $7.1 \%$ & $7.0 \%$ & $10.1 \%$ & $13.0 \%$ & $9.1 \%$ \\
\hline Once a week & $10.3 \%$ & $11.6 \%$ & $13.7 \%$ & $15.7 \%$ & $12.5 \%$ \\
\hline About once a month & $4.3 \%$ & $5.8 \%$ & $9.6 \%$ & $9.1 \%$ & $6.9 \%$ \\
\hline Less frequently & $28.4 \%$ & $30.6 \%$ & $27.5 \%$ & $24.4 \%$ & $27.8 \%$ \\
\hline Never & $43.9 \%$ & $38.4 \%$ & $33.1 \%$ & $24.4 \%$ & $36.1 \%$ \\
\hline Sum total & $\mathbf{1 0 0 . 0 \%}$ & $\mathbf{1 0 0 . 0 \%}$ & $\mathbf{1 0 0 . 0} \%$ & $\mathbf{1 0 0 . 0} \%$ & $\mathbf{1 0 0 . 0 \%}$ \\
\hline
\end{tabular}

From the viewpoint of our topic - the role of grandparents in the transmission of the faith - the following questions of the survey questionnaire appear as particularly significant: When you were a child, did someone teach you how 
to pray? If so, who was it? Please, enumerate all persons who taught you how to pray. In case of the question who taught them how to pray the respondents were offered the possibility to give more than one answer. If we look at the data presented in the table it becomes evident that the most important role in teaching children how to pray is played in the first place by mothers and immediately after them grandmothers follow. Fathers as teachers of prayer were indicated by surprisingly low number of respondents - slightly more than one forth $(28.6 \%)$ of them. The importance of father was surpassed by the figure of priest and catechist. They were indicated by roughly the same number of respondents. Grandfathers and godparents ended at the bottom of the table.

Tab. 4: The answers to the question: When you were a child, did someone teach you how to pray? If so, who was it? Please, enumerate all persons who taught you how to pray. $\mathrm{n}=1261$

\begin{tabular}{|l|c|c|}
\hline Answer & Abs. & $\mathbf{\%}$ \\
\hline Mother & 1016 & 80.6 \\
\hline Father & 361 & 28.6 \\
\hline Grandmother & 760 & 60.3 \\
\hline Grandfather & 156 & 12.4 \\
\hline Godparents & 97 & 7.7 \\
\hline Priest & 438 & 34.7 \\
\hline Catechist & 303 & 24.0 \\
\hline Others & 41 & 3.3 \\
\hline
\end{tabular}

The survey has shown that the role of mother is increasing from younger age groups to the elder ones. On the contrary, the role of grandmother is decreasing with the advancing age of the child. These are alarming results since they indicate that the role of mothers is increasingly taken over by grandmothers. The figure of father plays particularly small role among the respondents belonging to the age group 30-39 years. Logically, the role of catechist has special importance for the respondents belonging to the youngest age group since in Slovakia the figure of catechist as a teacher of religion only emerged in 1990; until then the communist regime made it impossible for laypeople to teach religion at schools. 
Tab. 5: The answers to the question: When you were a child, did someone teach you how to pray? If so, who was it? Please, enumerate all persons who taught you how to pray. (the variable of age taken into account) $n=1261$

\begin{tabular}{|l|c|c|c|c|c|}
\hline Answer Age & $\begin{array}{c}\text { Less than } \\
\text { 30 years }\end{array}$ & 30-39 years & 40-49 years & $\begin{array}{c}\text { 50 years } \\
\text { and more }\end{array}$ & Sum total \\
\hline Mother & 76.1 & 75.7 & 86.5 & 85.0 & 80.6 \\
\hline Father & 28.7 & 18.8 & 31.1 & 34.4 & 28.6 \\
\hline Grandmother & 66.2 & 60.3 & 57.8 & 53.4 & 60.3 \\
\hline Grandfather & 12.4 & 10.0 & 13.2 & 13.4 & 12.4 \\
\hline Godparents & 8.3 & 7.5 & 7.2 & 7.5 & 7.7 \\
\hline Priest & 33.8 & 36.4 & 34.4 & 35.2 & 34.7 \\
\hline Catechist & 42.1 & 20.5 & 12.3 & 11.9 & 24.0 \\
\hline Others & 4.4 & 2.9 & 2.7 & 2.4 & 3.3 \\
\hline
\end{tabular}

The data on practising prayer in the childhood were analysed by the researchers with regard to the indicators of respondents' current religious practices: the attendance of Holy Mass, their attitudes to it, the reception of Holy Communion, going to Confession, praying, reading the Holy Scripture and other religious books.

Tab. 6: The current frequency of going to Confession related to the answer to the question: When you were, say, 16 years old, did you pray together as a family? If you did so, how often was it? $\mathrm{n}=1255$

\begin{tabular}{|l|c|c|c|c|c|}
\hline $\begin{array}{r}\text { Going to } \\
\text { Confession }\end{array}$ & $\begin{array}{c}\text { About } \\
\text { once } \\
\text { a month }\end{array}$ & $\begin{array}{c}\text { Several } \\
\text { times } \\
\text { a year }\end{array}$ & $\begin{array}{c}\text { 1-2 times } \\
\text { a year }\end{array}$ & $\begin{array}{c}\text { Less } \\
\text { frequently } \\
\text { or never }\end{array}$ & Sum total \\
\hline Every day & $37.6 \%$ & $30.1 \%$ & $16.1 \%$ & $16.1 \%$ & $100.0 \%$ \\
\hline Several times a week & $28.7 \%$ & $40.0 \%$ & $18.3 \%$ & $13.0 \%$ & $100.0 \%$ \\
\hline Once a week & $13.3 \%$ & $38.0 \%$ & $27.8 \%$ & $20.9 \%$ & $100.0 \%$ \\
\hline About once a month & $16.1 \%$ & $29.9 \%$ & $25.3 \%$ & $28.7 \%$ & $100.0 \%$ \\
\hline Less frequently & $9.7 \%$ & $22.6 \%$ & $25.8 \%$ & $41.8 \%$ & $100.0 \%$ \\
\hline Never & $7.7 \%$ & $17.2 \%$ & $21.2 \%$ & $53.9 \%$ & $100.0 \%$ \\
\hline Sum total & $\mathbf{1 3 . 7 \%}$ & $\mathbf{2 5 . 3 \%}$ & $\mathbf{2 2 . 9 \%}$ & $\mathbf{3 8 . 1 \%}$ & $\mathbf{1 0 0 . 0 \%}$ \\
\hline
\end{tabular}


The data on the current religious practices were also compared among themselves with regard to the respondents' answers to the question on who taught them to pray when they were children and what prayers they were taught. It appears that from the viewpoint of practising religion later in life an active involvement of fathers in the raising of children and teaching them how to pray is of crucial importance. This phenomenon reveals among other things certain kind of split characterising the religious education in Catholic families in Slovakia. If we look at the data presented in the table we can see that the group of respondents who frequently attend the Holy Mass contain much higher percentage of persons who were taught how to pray by their father than the groups of respondents who attend the Holy Mass less frequently. Similar differences were also discovered with regard to the frequency of going to Confession.

Tab. 7: The Current frequency of attending the Holy Mass related to the answer to the question: When you were a child, did someone teach you how to pray? If so, who was it? Please, enumerate all persons who taught you how to pray.

\begin{tabular}{|c|c|c|c|c|c|c|c|}
\hline 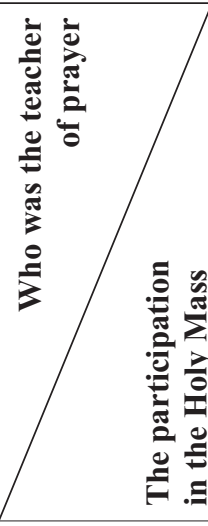 & 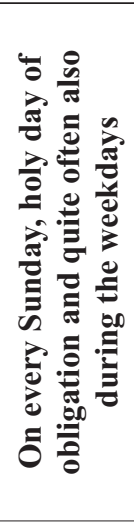 & 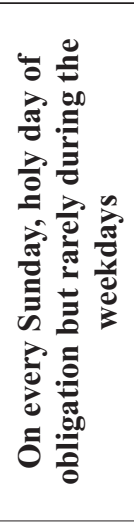 & 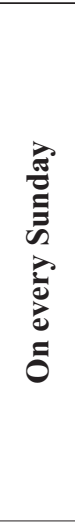 & 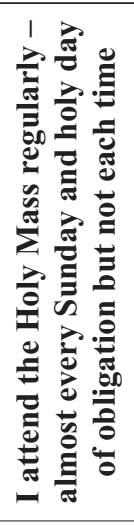 & 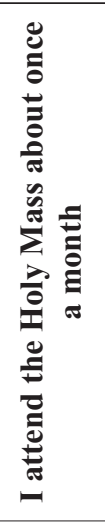 & 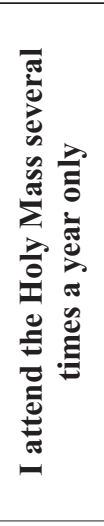 & 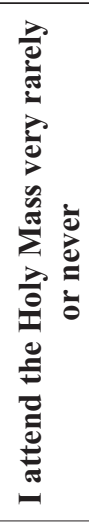 \\
\hline Mother & 89.3 & 91.9 & 88.0 & 84.6 & 76.3 & 73.1 & 64.5 \\
\hline Father & 41.6 & 41.1 & 29.6 & 30.9 & 27.5 & 18.7 & 13.7 \\
\hline Grandmother & 58.4 & 59.3 & 65.7 & 66.4 & 62.5 & 62.3 & 51.4 \\
\hline Grandfather & 13.4 & 15.9 & 12.0 & 11.4 & 12.5 & 11.7 & 8.2 \\
\hline Godparents & 10.7 & 8.9 & 9.3 & 10.1 & 6.3 & 6.0 & 4.4 \\
\hline Priest & 42.3 & 46.3 & 30.6 & 40.3 & 36.3 & 28.2 & 21.3 \\
\hline Catechist & 22.1 & 27.8 & 28.7 & 26.8 & 27.5 & 20.9 & 19.7 \\
\hline Others & 5.4 & 4.4 & 1.9 & 2.0 & 3.8 & 2.5 & 2.7 \\
\hline
\end{tabular}

Similar results were obtained examining the frequency of going to Confession. 
Tab. 8: The current frequency of going to Confession related to the answers to the question: When you were a child, did someone teach you how to pray? If so, who was it? Please, enumerate all persons who taught you how to pray.

\begin{tabular}{|l|c|c|c|c|}
\hline $\begin{array}{r}\text { Going to } \\
\text { Confession } \\
\text { the washer } \\
\text { of prayer }\end{array}$ & $\begin{array}{c}\text { About once } \\
\text { a month }\end{array}$ & $\begin{array}{c}\text { Several } \\
\text { times a year }\end{array}$ & $\begin{array}{c}\text { 1-2 times } \\
\text { a year }\end{array}$ & $\begin{array}{c}\text { Less } \\
\text { frequently } \\
\text { or never }\end{array}$ \\
\hline Mother & 92.4 & 88.2 & 81.8 & 70.3 \\
\hline Father & 45.0 & 35.4 & 29.1 & 17.2 \\
\hline Grandmother & 57.9 & 61.8 & 62.7 & 58.7 \\
\hline Grandfather & 15.8 & 14.9 & 13.0 & 8.8 \\
\hline Godparents & 14.0 & 9.9 & 5.5 & 5.2 \\
\hline Priest & 40.9 & 44.7 & 34.9 & 26.0 \\
\hline Catechist & 23.4 & 28.9 & 23.6 & 21.7 \\
\hline Others & 3.5 & 4.3 & 2.7 & 2.8 \\
\hline
\end{tabular}

The respondents also gave answers to the questions on how often they attended the Holy Mass when they were children (10 years old) and young people (18 years old). In addition to this the researchers asked them how often their mother attended the Holy Mass when they were children and the same about their father. The data presented in the table reveal that compared to childhood the frequency of attending the Holy Mass in young age is significantly lower. When they were 10 years old, about $4 / 5$ of the respondents $(79.7 \%)$ regularly attended the Holy Mass at least once a week. At the age of 18 only slightly more than $1 / 2$ of the respondents did the same $(54.4 \%)$.

Tab. 9: The answers to the question: How often did you attend the Holy Mass when you were a child and later when you were a young person?

\begin{tabular}{|l|c|c|}
\hline Answer & $\begin{array}{c}\text { At the age of 10 } \\
\mathbf{n = 1 2 9 1}\end{array}$ & $\begin{array}{c}\text { At the age of 18 } \\
\mathbf{n = 1 2 9 1}\end{array}$ \\
\hline Several times a week & 24.9 & 11.1 \\
\hline Once a week & 53.8 & 43.3 \\
\hline 2-3 times a month & 6.6 & 7.7 \\
\hline
\end{tabular}




\begin{tabular}{|l|c|c|}
\hline Answer & $\begin{array}{c}\text { At the age of 10 } \\
\mathbf{n = 1 2 9 1}\end{array}$ & $\begin{array}{c}\text { At the age of 18 } \\
\mathbf{n = 1 2 9 1}\end{array}$ \\
\hline About once a month & 3.0 & 5.5 \\
\hline Several times a year & 3.4 & 7.0 \\
\hline $\mathbf{1 - 2}$ times a year & 1.2 & 5.0 \\
\hline Less frequently & 3.6 & 12.9 \\
\hline Never & 3.6 & 7.4 \\
\hline Sum total & $\mathbf{1 0 0 . 0}$ & $\mathbf{1 0 0 . 0}$ \\
\hline
\end{tabular}

The table No.10 presents the data on the answers of the respondents to the question on how often their parents attended the Holy Mass in the past, when the persons giving the answer were children. The results show that mothers attended the Holy Mass more frequently. As for fathers, more than half of them attended the Holy Mass less often than once a week.

Tab. 10: The answers to the question: How often did your parents attend the Holy Mass when you were a child?

\begin{tabular}{|l|c|c|}
\hline Answer & $\begin{array}{c}\text { Father } \\
\mathbf{n = 1 2 8 8}\end{array}$ & $\begin{array}{c}\text { Mother } \\
\mathbf{n = 1 2 8 7}\end{array}$ \\
\hline Several times a week & 7.2 & 23.5 \\
\hline Once a week & 40.8 & 45.8 \\
\hline 2-3 times a month & 7.8 & 5.6 \\
\hline About once a month & 4.7 & 2.9 \\
\hline Several times a year & 5.5 & 6.0 \\
\hline 1-2 times a year & 5.5 & 3.5 \\
\hline Less frequently & 10.9 & 6.2 \\
\hline Never & 14.3 & 5.7 \\
\hline $\begin{array}{l}\text { I did not live with my father/ } \\
\text { mother }\end{array}$ & 3.2 & 0.9 \\
\hline Sum total & $\mathbf{1 0 0 . 0}$ & $\mathbf{1 0 0 . 0}$ \\
\hline
\end{tabular}

The respondents were also asked if and how often they talked about religious issues with their parents or other persons when they were children/ 
/young people. The data presented in the table show that in addition to parents an important role in this element of religious socialisation was played by grandparents and priests.

Tab. 11: The answers to the question: When you were a child/young person, did you talk about religious issues with your parents or other persons? (\%)

\begin{tabular}{|l|c|c|c|c|c|}
\hline & Often & Seldom & Never & Sum total & n \\
\hline Parents & 29.9 & 52.4 & 17.7 & 100.0 & 1272 \\
\hline Grandparents & 27.5 & 43.5 & 29.0 & 100.0 & 1238 \\
\hline Brothers and sisters & 8.2 & 31.8 & 60.0 & 100.0 & 1184 \\
\hline Godparents & 4.9 & 21.8 & 73.3 & 100.0 & 1165 \\
\hline Priest & 21.7 & 36.1 & 42.2 & 100.0 & 1191 \\
\hline Catechist & 16.5 & 26.0 & 57.5 & 100.0 & 1161 \\
\hline
\end{tabular}

The survey has revealed a particular role played by mothers and grandmothers in the process of transmitting faith as well as a high degree of absence of fathers in this process and probably in the whole task of raising children (Matulník, Kratochvíla, Kyselica 2008, 166-178).

The following sociological survey examining the religiosity of young Catholics in Slovakia was carried out in the scholastic year 2012/2013 among the group of 17-year-old. It was focused on the issue of transmitting the faith in the family and the way it is perceived by young generation. The analysis of family environment and the religiosity of young people in Slovakia provided results similar to those produced by foreign surveys, above all the finding that there exists positive correlation in all measured aspects between the degree and quality of religiosity and the quality of family environment.

Two thirds of the respondents perceive the atmosphere in their families as positive. About a third of the respondents believe that their parents do not understand them much or at all - they have little or no idea of how they think, what they do and why, how they behave and for what reasons, and what they feel. Only $17.9 \%$ of the respondents talk to their parents very often. On the other hand, $19.5 \%$ of them do not talk to them at all. A half of young students indicated that they find it very or rather easy to talk with their parents about sensitive topics. On the contrary, the second half of the respondents found it rather or very difficult to do so.

The joint family activities were evaluated by the respondents in two separate categories - at home and out of the house. As far as indoor activities are 
concerned, $25.9 \%$ of the respondents indicated that in the previous month they did something together as a family several times a week. Only $16.4 \%$ of them indicated that their family did not do any joint activity during the previous month. The joint family activities performed out of the house are less frequent - only $6.5 \%$ of the respondents do such activities several times a week. $23.5 \%$ of the respondents did them at least once a week.

The trust of parents for their children can be measured according to the degree to which the former are informed about the activities the latter perform out of the house and in terms of the answer to the question if the situation occurred that the child left house and spent at least one night out of it without the consent of parents. This happened to almost a third of the respondents. In $43.1 \%$ of the cases parents are always or most of the times informed about the activities of their children.

The students were also asked the question if they enjoy the support of their parents finding an outer expression through the way the latter behave towards the former and how they act. The relationship with the mother got significantly higher valuation than the closeness to the father; mothers appear to provide stronger emotional support than fathers. This result is caused among other things by the fact that $8.6 \%$ of the respondents selected the option "irrelevant to me", which roughly corresponds to the percentage of young population lacking any contact with father.

Analysing the differences between Catholics and non-religious people in the ways of performing family activities statistically significant differences were detected between the joint family activities at home and out of the house. In both cases higher frequency was detected in the group of respondents-Catholics. Similarly Catholic parents are better informed about the activities of their children out of the house and young Catholics leave house and stay overnight out of without the consent of parents it less frequently than other groups.

As we have seen, the survey on the religiosity of Slovak Catholics in the productive age evealed low level of fathers' and grandfathers' participation in the process of transmitting the faith (see the table No. 7). Similarly the analysis of the correlation between the characteristics of family environment and religiosity carried out in the examined survey on the religious attitudes and behaviour of young people revealed the differences related to the composition of the respondent's household. An important role is played by the presence of one's biological father - in comparison to other respondents the young people living in the household comprising their own father practise the faith in more cases and more of them suppose they will be going to church at the age of 25 .

To be more specific, only $33.3 \%$ of the respondents growing up without father go to church while in the case of young people living in a household with father it is $47.5 \%$. Similar results were obtained with regard to Confession: 
young people growing up without father go to Confession in $30.3 \%$ of cases while those who live in a household with their own father do so in $46 \%$ of cases. In comparison with young people living without father higher percentage $(56.7 \%)$ of those who live with the father suppose they will be going to church at the age of 25 . In case of the former it is only $49.6 \%$.

Similarly important role is played by grandparents. Young people living in households counting at least one grandparent go to church more often than their peers who are different in terms of their relationship with grandparents $(61.2 \% / 51.7 \%)$. Similarly higher percentage of the former $(62.2 \%)$ supposes they will be going to church at the age of 25 compared to the respective percentage of the latter (50.4\%). The respondents living in a household with grandparent(s) also develop more intensive sense of belonging to the parish community $(54.6 / 40.0 \%)$.

The third factor analysed with regard to the composition of the respondents' household was the presence of sibling(s). In this case, too, significant differences were detected between the respondents living in a household with and without sibling(s). The respondents living with sibling(s) go to church and Confession more often and in more cases suppose they will be going to church at the age of 25. Besides, in families like this the joint prayer before meals is practised more often. Another interesting finding: more respondents living with sibling(s) consider the Sunday Mass obligation as adequate to the requirements of the present time than those who do not have sibling(s). In the case of all examined variables the score of young people living in household with sibling(s) exceeds the score of respondents without sibling(s) by more than 10 percentage points.

To sum up, the practising of individual as well as joint family prayer, attending Mass and the respondents' belief that they will be going to church even at the age of 25 are positively correlated with the frequency of the joint family activities at home and out of the house. The religiosity of young people is also positively correlated with the degree to which their parents are informed about their activities out of the house - the more important role the religion plays in the life of adolescent, the more his/her parents know about what activities he/ she performs out of the house. Similar correlation exists between the degree to which the parents are informed about the activities of adolescent and the frequency of prayer, going to confession as well as his/her belief that he/she will be going to church even at the age of 25 . The expressions of religiosity are negatively correlated with the phenomenon of leaving house and spending at least one night out of the house without the consent of parents.

The importance the religion plays in the life of young people is also positively correlated with the family atmosphere. There exists positive correlation between the quality of this atmosphere and the joint family prayer before 
meals as well as taking personal decision to start going to church. Even the degree of mutual understanding between parents and their children is positively correlated with the importance played by the religion in the life of students as well as the intensity of their prayer life. ${ }^{2}$

The survey has shown that the index of family relationships reflecting the overall situation of the examined families, family atmosphere and the quality of the relationships between parents and children is positively correlated with all dimensions of religiosity that have been taken into account. It means that the more important role is played by religion in the life of a young person, the more often he/she prays and attends Mass, the more intensive sense of belonging to the parish community he/she develops, the more often he/she goes to Confession, the firmer his/her belief that the priestly vocation is important for today's society and that he/she will be going to church even at the age of 25 , the better relationships flourish in his/her family. In turn, family climate is inter alia positively correlated with the importance attributed by students to their school reports and scholastic performance. Better family atmosphere is also positively correlated with the attendance of sporting and cultural events. Last

${ }^{2}$ The phenomena related to the issues of family and family atmosphere were measured by means of questions about joint family activities performed at home and out of the house, social climate of the family, the intensity of communication between children and parents about sensitive topics, the degree of mutual trust between them and their attitudes towards cohabitation. The researchers created an index of family relationship based on the questions listed below which were verified by means of Cronbach's Alpha. The resultant value amounting to 0,716 attests to the fact that the index was construed in a reliable way. The answers to the questions were valued using interval markings of 0-100 ( 0 - low level of relationships between students and their parents, $100-$ high level of the relationships).

List of questions:

How often do your parents know where you are and what yo do when you are not at home?

Did you ever leave house and spend at least one night out of the house without your parents knowing about it or giving you consent?

Do your parents (at least one of them) know your friends?

How often did your family perform joint indoor activities during the previous month (e.g. playing a table game, watching a television program or film together as a family for at least one hour, doing DIY together)?

How often did your family perform joint outdoor activities during the previous month (e.g. doing sports together, jointly attending a sporting or cultural event, going on a hike together as a family)?

How would you characterise the atmosphere prevailing in your family (peaceful, friendly, or, on the contrary, rather tense, less friendly)?

To what extent do you feel that your parents understand you, the way you think, what you do and why, how you behave and what feelings you experience?

Do you talk with your parents about the topics that can be sensitive, for example about the relationships with your friends and young persons of the opposite sex, or about the consummation of alcohol? If so, how often do you do that?

Do you find it difficult or easy to talk with them about these sensitive topics? (Kratochvíla 2014, $120)$. 
but not least, the survey has confirmed the widely recognised fact that better relationships in family are negatively correlated with drug abuse, smoking and alcohol abuse (Kratochvíla 2014, 153-156).

\section{Conclusion}

In recent years the interest in multigenerational housing showed by young families has increased also in Slovakia. It can be perceived as a positive trend. Multigenerational house appears to be a bridge connecting tradition with the future - the grandparents can contribute to the common "family pot" with the treasures hidden in their memory and their testimony to the faith while the grandchildren can "spice" it adding the courage and confidence with which they look towards the future. In the past the multigenerational housing was a necessity, today it is an option realisable on condition that the living area of the house is sufficiently large, both parents and grandparents have clearly defined "territories" and, even in case they share some spaces in the house, each household has its own, completely separated bedroom, kitchen and bathroom. It means that the households are two separated units living under one roof able to help each other hand when necessary. It is a seemingly paradoxical but in fact perfectly viable and mutually beneficial synthesis of independence and interdependence. The arguments for this type of housing advanced by developers are not based on its financial advantages only, but also on the possibility of mutual help, for example with the care of little children and the raising the new generation, weaving the web of broader family relationships and deepening them. Again, all of this is possible, but only on condition that the house is designed in such a way that helps to clearly define the rules regulating the coexistence of both households and the use of common spaces. ${ }^{3}$

In conclusion we can say that the increasing trend towards multigenerational housing is not a mere sociological phenomenon but in addition to this it represents an ideal opportunity for a more active involvement of grandparents in the process of the transmitting the faith in family.

${ }^{3}$ Cf. https://www.nehnutelnosti.sk/magazin-o-byvani/38820-rozumiete-si-s-blizkymi-podeltesa-o-byvanie-v-dvojgeneracnom-dome/ [accessed: 12.07.2018]. 


\section{DZIADKOWIE A PRZEKAZ WIARY I CHRZEŚCIJAŃSKI STYL ŻYCIA}

\section{Streszczenie}

W przeszłości wielopokoleniowe budownictwo mieszkaniowe było koniecznością ze względów ekonomicznych. Młode rodziny stopniowo zdobywały środki umożliwiające im uniezależnienie się od rodziców. Ogólny wzrost gospodarczy i postępująca urbanizacja umożliwiły młodym rodzinom znacznie szybsze uzyskanie niezależności. Jednak z punktu widzenia przekazu wiary i chrześcijańskiego stylu życia rozwój ten naruszył naturalną ciągłość międzypokoleniową. Młode rodziny często nie są w stanie zmienić sposobu, w jaki przeżywają swoją wiarę, na odpowiedni styl życia, który był w sposób naturalny przekazywany z pokolenia na pokolenie. Badania religijności na Słowacji pokazują pozytywny wpływ dziadków na przekazywanie wiary. Najważniejszymi osobami w tym obszarze są matki i babcie, natomiast typowy jest brak uczestnictwa w tym procesie ojców i dziadków. W ostatnim czasie obserwujemy trend w kierunku odnowienia budownictwa wielopokoleniowego z większą powierzchnią mieszkalną, łączącego autonomię rodziny nuklearnej z bliskością dziadków. Pod warunkiem, że obie strony przestrzegają wspólnie uzgodnionych zasad regulujących ich współistnienie i korzystanie z części wspólnych, takie budownictwo mieszkaniowe może być dla każdej z nich wzbogacające.

Słowa kluczowe: modlitwa w rodzinie, Kościół domowy, budownictwo wielopokoleniowe, solidarność międzypokoleniowa

Keywords: prayer in the family, domestic church, multigenerational housing, intergenerational solidarity

\section{BIBLIOGRAPHY}

Braunsteiner, Gloria. 2016. Systematický pohl'ad na dnešné manželstvo. In Hlavné línie riešenia projektu APVV 15-0189 «Vybrané faktory pro-rodinnej stratégie a podpora stabilnej rodiny $v$ multikulturálnom prostredì v roku 2016., ed. Ladislav Csontos. 21-24. Trnava: Dobrá kniha.

John Paul II. 1979. Apostolic exhortation Catechesi tradendae.

Kratochvíla, Michal. 2014. Rodinné prostredie. In Analýza religiozity mladých katolikov na Slovensku. Poznatky zo sociologického výskumu, eds. Jozef Matulník. 119-157. Trnava: Dobrá kniha.

Matulník, Jozef et all. 2008. Odovzdávanie viery det’om v rodine. In Analýza religiozity katolikov na Slovensku. Poznatky zo sociologického výskumu. eds. Jozef Matulník et al. 158-223. Trnava: Teologická fakulta Trnavskej univerzity v Trnave.

Rocchetta, Carlo. 2011. Teologia della famiglia. Fondamenti e prospettive. Bologna: Edizione Dehoniane Bologna. 
LADislav Csontos SJ - prof. dr hab., od 1994 roku wykłada antropologię, filozofię kultury, logikę i teologię rodziny na Wydziale Teologicznym Uniwersytetu w Trnavie. W latach 1997-2003 pełnił funkcję dziekana Wydziału Teologicznego oraz od 2011 do 2015 roku prorektora tej uczelni. W latach 2016-2020 realizował projekt pt. „Wybrane czynniki strategii prorodzinnej i wsparcie stabilnej rodziny w środowisku wielokulturowym" Autor 11 monografii naukowych, 5 podręczników uniwersyteckich oraz wielu artykułów naukowych. Został wyróżniony przez Konferencję Episkopatu Słowacji w 2015 nagrodą „Fides et Ratio” oraz w 2019 r. przez Przez Papieski Wydział Teologiczny w Warszawie tytułem doktora honoris causa. 